\title{
ORATORIOS BY AMANDUS IVANSCHIZ IN THE CONTEXT OF MUSICAL SOURCES AND LITURGICAL PRACTICE ${ }^{1}$
}

Fr. Amandus Ivanschiz was most likely born on December 24, 1727 which was the day he was baptized in Wiener Neustadt (Austria), with the names of Matthias Leopold. ${ }^{2}$ In December 1743 he entered the Pauline Order and took the name Amandus. After receiving his Holy Orders, the years 1751-54 he spent in Rome, where he served as a socius of the Procurator General of the Order. Soon after his return, in 1755, Ivanschiz was moved to the Maria Trost monastery near Graz, where he died in 1758, in the age of merely thirty-one. About one hundred compositions by Fr. Amandus have come down to us. His oeuvre includes both instrumental works, and vocal-instrumental sacred music. Apart from numerous manuscripts of doubtful attribution, the firs group comprises about 20 symphonies and 13 string trios. The second group is more extensive, and contains 17 masses, 13 litanies, 7 Oratorios, 9 settings of Marian antiphons, 8 arias and duets to non-liturgical texts, as well as vespers and Te Deum. Many of these works have survived in a few or even a dozen or so copies, which are now found in many, mainly Central European countries, such as Austria, Belgium, Croatia, Czech Republic, Germany, Hungary, Poland, Slovakia, Slovenia, Sweden and Switzerland. It proves that Father Amandus' music was known to a wide audience and places him among the most popular monk-composers of the $18^{\text {th }}$ century.

1 The author of this article conducted studies on Father Amandus Ivanschiz's life and work, originally in the context of his doctoral dissertation dedicated to that composer's religious music (see footnote 2), and currently within the research project, which aims at producing a monograph as well as a full thematic catalogue of Ivanschiz's works. The project is financed from the Polish National Science Center's funds awarded on the basis of the decision number DEC-2011/03/N/HS2/00853. Maciej (ed.). Amandus Ivanschiz: Missa in C. Musica Claromontana vol. 10, Cracow, 2013, p. 4-17. JOCHYMCZYK, Maciej. Twórczość religijna o. Amanda Ivanschiza OSPPE [Religious music by Fr. Amandus Ivanschiz OSPPE]. Doctoral dissertation, Institute of Musicology, Jagiellonian University, Cracow, 2012. Publication pending. The selected excerpts of this article are based on the fragments from the dissertation. 
Oratorios by Ivanschiz were written during the final years of his life. They were commissioned by the Jesuits from Graz, as is testified by entries in the account books of the St. Ägidius church, presently the Graz Cathedral. Seven partially incomplete Oratorios have survived among other musicalia originating from the Jesuit college of Győr in Hungary, and are currently kept at the Benedictine monastery in Pannonhalma. ${ }^{3}$ Another copy of one of the above mentioned works could still be found in the 1970's in the collections of Benedictine abbey in Seckau in Austria. This manuscript, however, needs to be presently considered lost.

The Oratorios turned out problematic for a present-day researcher because the genre category specified on the title pages, would not fully match the form of the compositions. Using today's typology, we would be rather inclined to call these not too extensive works church cantatas, as they comprise of an instrumental introduction, a recitative, an aria and a short final chorus. In fact, also music theorists from the $18^{\text {th }}$ and the beginning of the $19^{\text {th }}$ century considered the length of the composition a primary factor in determining the genre classification of a (shorter) cantata or an (longer) oratorio. Among them were Johann Mattheson (Grundlage einer Ehren-Pforte, Hamburg 1740) ${ }^{4}$ and Heinrich Christoph Koch (Musikalisches Lexikon, Frankfurt 1802). ${ }^{5}$ It should be noted, however, that, with reference to religious music, both terms - 'oratorio' and 'cantata' - functioned interchangeably for a long time after Ivanschiz's death. The article Cantate published in the first volume of Allgemeine Theorie der Schönen Künste by Johann Georg Sulzer reads: „Es giebt zweyerley Gattungen der Cantaten, kleinere, für die Cammermusik, darin weder ein vielstimmiger Gesang, noch vielstimmige Begleitung verschiedener Instrumente vorkommt; und grössere zur feyerlichen Kirchenmusik, darin Chöre, Choräle und andre vielstimmige Gesänge und eine starke Besetzung von verschiedenen Instrumenten statt hat. Diese werden insgemein Oratoria genennt" ${ }^{\text {" }}$

Nearly all Oratorios in their current form, praise the Jesuit saints. Lyrics for two compositions (Oratorium Xaverianum and Oratorium 2 dum De Sancto Xaverio) were written in German, while the remaining five (marked as Oratorium $1,2,3,4$, and 5) in Latin. The texts are usually poetic, constructed with more or less regularly formed and rhyming verses. The Latin compositions were mainly dedicated to St. Aloysius Gonzaga (nos. 2, 3 and 5), while the both works with the

3 H-PH, Musicotheca Jesuitica: Oratorium 1 $1^{\text {mum }}$, call no.: 141; Oratorium 2, call no.: 142; Oratorium 3, call no.: 143; Oratorium 4tum de S. Aloysio et se SS. Corde Jesu, call no.: 144; Oratorium 5, call no.: 145; [Oratorium Xaverianum], call no.: 157c; Oratorium 2 dum De Sancto Xaverio, call no.: 146.

4 See: SMITHER, Howard E. A History of the Oratorio. Vol. 2: The Oratorio in the Baroque Era: Protestant Germany and England. Chapel Hill, 1977, p. 106.

5 See: SMITHER, Howard E. A History of the Oratorio. Vol. 3: The Oratorio in the Classical Era. Oxford, 1987, p. 339.

6 SULZER, Johann Georg. Allgemeine Theorie der Schönen Künste. Vol. 1. Leipzig, 1771, p. 191-192. 
German text - to St. Francis Xavier. The only exceptions here are Oratorium 1, with its two rather general texts of a laudatory character (the second one added later) and Oratorium 4, with its first text addressing the Most Sacred Heart of Jesus. The Latin compositions marked with the numbers $2-5$ were also adapted so that they could be performed in honor of the founder of the Society of Jesus, St. Ignatius Loyola. The meaning of the verbal layer was universal, so only the name 'Aloysius' or the last name 'Gonzaga' needed to be changed to 'Ignatius' or 'Loyola', respectively (Ex. 1).

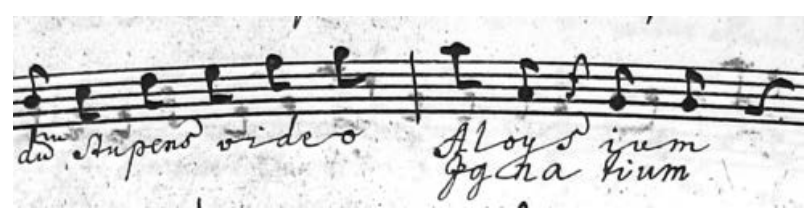

a) recitative

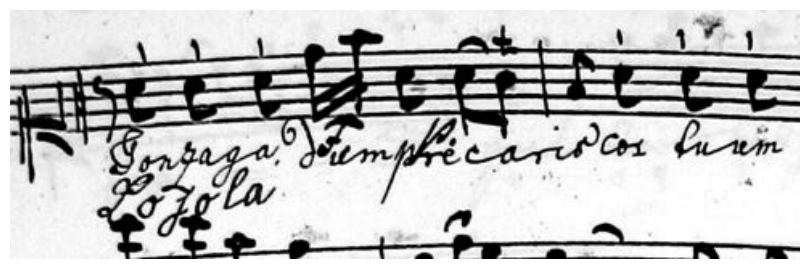

b) aria

Ex. 1: Oratorium 3, fragments of canto part

The only exception constituted the middle part of an aria from Oratorium 2 as well as the whole Oratorium 4, where entirely new lyrics were added. Surprisingly, while the two texts included in the second manuscript relate to the Heart of Jesus and to St. Ignatius Loyola, an inscription on the title page reads „de S. Aloysio et de SS. Corde Jesu". Therefore, can we assume that, originally, even different lyrics may have been used for this work? Indeed, the analysis of the manuscripts of Latin Oratorios by Ivanschiz as well as the compositions themselves, show that probably none of the texts contained in the sources is original. Taking the most crucial doubts into consideration, we may state that:

- the text to Oratorium 1 recitative was most likely added later on by a different person than the one who wrote the lyrics to the aria and chorus; in the context of the eighteenth-century sources this fact alone would not be so unusual, however, contrary to the principle that applied to the remaining compositions of this genre, this is not a religious poetry but rather a liturgical text - an antiphon 'Domine iste sanctus habitabit...'; 
- the final choruses of all Oratorios, with the exception of the first and the fifth ones, begin with a few bars of Adagio introductions; an analogous introduction was present also in the composition no. 3, yet it was erased and no text was added to it (ex. 2a);

- in the chorus section of Oratorium 4 one of the texts does not correspond with the number of notes in the bars (ex. 2b; b. 2, 4, 6, 7);

- there occurs an already mentioned inconsistency between the purpose stated on the title page of Oratorium 4 and the actual words of the composition;

- the fact that in some compositions of this genre, of almost identical music structure, texts in Latin are used, while in others - German, may also point to the lack of originality of the lyrics.

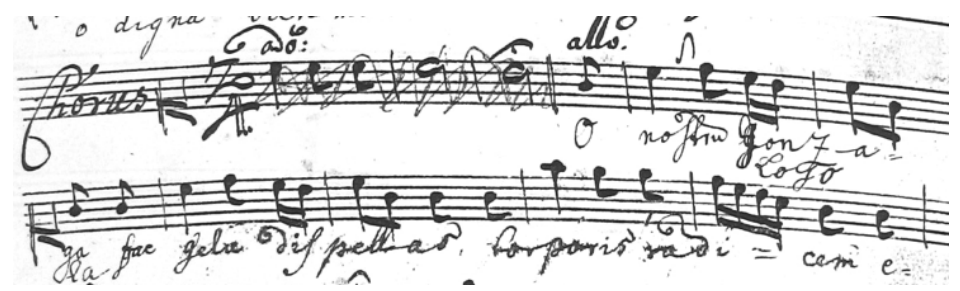

a) Oratorium 3, fragment of canto part

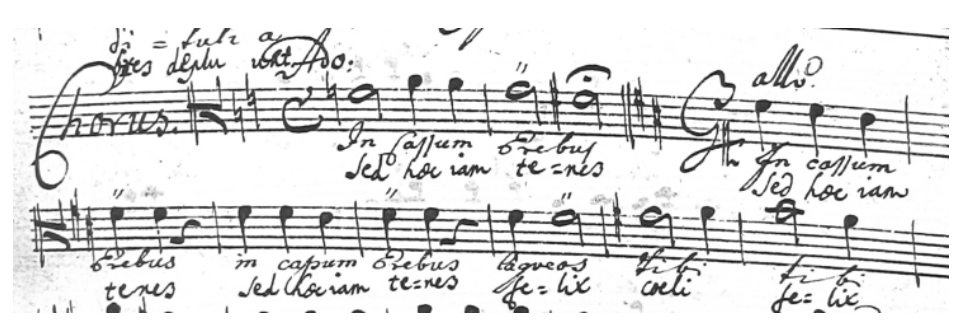

b) Oratorium 4, fragment of alto part

Ex. 2: Fragments of the selected manuscripts of Oratorios

Music-rhetorical figures and other musical illustrations, which could prove the originality of the texts, appear seldom, even though pithy, at times rather drastic descriptions of sufferings of saints are present there (for example „Crudelis in se paenitens / Gonzaga licet innocens / in suo notat sanguine / discerpta flagris hiat cutis / tanta insonti est cura salutis", which could be translated as: 'Staunch in his penance, innocent Gonzaga shows through his blood, mortifying his flesh, a resounding within him concern for salvation'). Among the exceptions would be the recitative 'Tartareae abeste hinc furiae' from the composition no. 5, where the solo sections of basso continuo part could be seen as an attempt at musical portrayal of these infernal furies. 
As it follows from the above arguments, it is very likely that Ivanschiz's Latin Oratorios kept in Pannonhalma, were not composed to the lyrics found in the sources today. In case of the Oratorium 1 recitative, and also the choral parts of the compositions no. 3 and 4 it seems almost obvious. Certain technical shortcomings present in the recitatives of all of the discussed works of this genre make one to ponder whether the original versions were in fact the same as we know them today. Even though the presence of analogous formal structures (with a recitative) in manuscripts of diverse provenance (Györ, Seckau) points to the authenticity of general principles of the musical layer, it does not, yet, mean that the works were not modified, for example in a (hypothetical) process of adjusting them to fit a new text.

An explanation of this and other issues related to Fr. Amandus' Oratorios is provided by an analysis of the Jesuit archives and account books from St. Ägydius Church in Graz, the very same in which Ivanschiz's name is mentioned in connection with music expenses. From them emerges quite a coherent picture of a musical practice of this center in regard to oratorio genre, which, because of its importance and documentative significance, we shall herein present in detail. ${ }^{7}$ The surviving account books cover the period from 1699 to $1770 .{ }^{8}$ The expenses are divided into a few categories, such as the purchase of liturgical vestments, maintenance of the altars, and conducted services. In the section Pro Sacello S. Xaverii (later In Novennam S. Franc. Xaverii) we find regular expenses for music which was intended for the novena to St. Xavier, celebrated yearly from 25 November to 3 December. The term 'oratorio' starts appearing there since 1732. ${ }^{9}$ Also the section called In Novennam S. P. Ignatii initiated in 1729 has a very similar content (yet when it comes to the subject considered, it is slightly poorer) ${ }^{10}$ What is interesting is that the entries clearly indicate that the libretti

7 Apart from the surviving books, the most important source of information about the beginnings of oratorio in Graz constitutes an article by FLOTZINGER, Rudolf. Die Anfänge des Oratoriums in Graz. Historisches Jahrbuch der Stadt Graz, 1986, no. 16/17, p. 21-32.

Diözesanarchiv, Graz (A-Gd), call no.: XX-C-10 (1699-1734), XX-C-11 (1735-1746), XXC-13 (1747-1770).

From the sources cited here we learn that in the years 1747-1758 a term 'Oratorio' was used interchangeably with 'Cantate'. It seems that the semantic range of these words starts to diverge after 1758, see FLOTZINGER, op. cit., p. 22.

10 A list of the select expenses for music as per Exposita templi S. J. Ab anno 1747, A-Gd, call no. XX-C-13:

In Noven: S. P. Ignatii

'Anno 1747: Compositori textus Germ. Oratorii - 4,12; In Manus Compositori D. Christophoro Wagenseil - 8,24. Anno 1748: Pro uno Sacro Cantato novo descripto - 1,50; Pro Novem Ariis et Motteta cum textu, descriptione et charta - 11,3. Anno 1764: Pro sacro cant. descripto - 6,36. Anno 1765: In Musicalia, et descriptione - 10,34. Anno 1767: In musicalia nova - 12,30; Descriptionem oratoriorum - 17,20; Compositori oratorii germanici - 12,40. Anno 1768: In descriptionem 8 Lyt. et Cant. Authore Schenck - 11,36; Compositori Musicae - 12,22. Anno 1770: Compositori textus pro oratorii de S. P. Ignatio - 4,12; Pro impressione Oratorii 500 Exempl - 4,18; In 3000 Exempl. novae Cantilenae de Eodem Sancto - 5,6; Compositori oratorii ad notas musicas $-20,50$ '. 
of the compositions were printed in high volumes. Texts published in such large quantities could not have disappeared without a trace. The copies from 17151721, 1723, 1725, 1727-1729, 1731, 1734, 1735, 1737, 1740, 1742, 1744, 1745, $1759,1766-1770$ and $1772,{ }^{11}$ as well as two editions documenting performances of the oratorios dedicated to St. Ignatius Loyola, from 1767 and $1773^{12}$ have survived to our times. Unfortunately the libretti from the period of Ivanschiz's activity (1755-1758) are missing. Nevertheless the analyses of the preserved material make it possible to draw a few crucial conclusions pertaining to the structure and the lyrics of the compositions. First of all, the known libretti, without an exception, were written in German. This fact, yet again, questions the originality of the Latin texts that we know from the manuscripts of five Oratorios from Pannonhalma. The compositions performed at the Jesuit church in Graz had initially most

In Noven: S. Franc: Xaverii

'Anno 1747: In descriptionem novissimi Sacri cantati eleganti - 2; Typographo pro 700 oratoriis - 6,15; In descriptionem Lytaniarum, oratorii musici [...] - 3,54; Compositori Musici oratorii - 21. Anno 1748: Compositori textus oratorii - 4,7,2; Compositori Musicae Honorarium munus - 12,25; Typographo pro oratoriis 500 Novenna. Anno 1749: Compositori Musices - 31,24; In descriptione musicae - 8,6. Anno 1750: In descriptionem Musicae 2,12. Anno 1751: Typographo pro impressis libellis Xaverianis - 5,48; Eidem pro impressis 600 oratoriis $-4,45$; Compositori textus pro oratoriis $-4,10$; Compositori Musices -21 . [...] Anno 1754: Compositori oratorium - 4,12; Pro descriptione musicae - 1,22. Anno 1755: Compositori musices pro 5 oratoriis - 24; Compositori textus oratorii $-4,12$; Pro curru, quo ex Mariae Consolatricis Monasterio ad probandam musicam vectus est V. P. Compositor Amandus Ivantschiz - 1,30. Anno 1756: Compositori Musices pro 5 oratoriis - 20,50; Compositori textus oratorii - 4,10; Descriptori musices - 8,54. Anno 1757: Compositori musices pro 5 oratoriis -21 ; Compositori oratorii textus $-4,21$. Anno 1758: Compositori musices pro 5 oratoriis -21 ; Compositori textus oratorii $-4,12$ '.

Sauraujan pro 6. Dom. S. Aloysii

'Anno 1747: Compositori Musicae in 6 Dom. cum descriptione - 21. Anno 1748: Compositori textus pro 6 Ariis S. Aloysii - 4,12; Pro 6 Ariis ad Lytanias S. Aloysii in 6 Dominicis -2'. In Varia

'Anno 1758: Pro 5 lytaniis et uno Sacro Cantato a VP. Amando Ivantschiz compositis - 20'.

11 Ibid., p. 24. The following texts of oratorios have survived: Geistlicher Streit etlicher Königreich und Länder... 1715; Schutz-Baum Nabuchodonosoris. Oder wunder-reich Franciscus Xaverius... 1716; Die in ihrem Auffgang, Mittag und Nidergang betrachtete Sonne... 1717; Xaverianischer Himmels-Sig... 1718; Xaverianischer Tugend-Streit...1719; Xaverianischer Phönix... 1720; Neu-Testamentischer Moyses... 1721; Der auß dem grossen Welt-Lager sich begebende [...] heilige Franciscus... 1723; Trauerndes Europa und frolockendes India... 1725; Das betrübte [...] Europa... 1727; Der von eigener Liebe obsigende... 1728; Göttlicher Liebes-Thron... 1729; Siegender Schlaf-Kampf... 1731; Ungemeine Liebes-Stärke... 1734; Heiliger Franciscus Xaverius... 1735 i 1737; Danck-Opfer des Hertzogthums Steyermarck... 1740; Schuldigstes Lob und Dancksagung... 1742; Bitt-Seufzer einer Gott liebenden Seele... 1744; Fünf-fache Tugend-Zierd Xaverii... 1745; Die Abreise des heiligen Franciscus aus Portugal... 1759; Die Starkmuth des heiligen Franciscus... 1766; Des heiligen Franciscus Xaverius Vertrauen... 1767; Grundfeste der Größe... 1768; Des heiligen Franciscus Xaverius Beruf... 1769; Der Tod des heiligen Franciscus Xaverius... 1770; Die Liebe des heiligen Franciscus Xaverius... 1772.

12 Ibid., p. 24: Ein geistliches Singgedicht über die Worte: Wie verächtlich ist mir die Erde... 1767; Standhaftigkeit des heiligen Ignatius von Lojola... 1773. 
likely one-part structure ${ }^{13}$ However, soon after, a two-part form developed, in which either only the first or both parts would begin with an instrumental intrada (years 1718, 1719, 1721, 1723, 1728, 1731). This structure began to gradually expand into a four- or even five-part composition (in 1740 and 1745, respectively), which remained as such until the dissolution of the order in $1773 .{ }^{14}$ Even though the structure was complex, the compositions were rather simple - each of the five parts contained an opening sinfonia, a recitative, an aria and a final chorus. What is important that these parts were performed separately - most likely one on each odd day of novena. Soon, however, also these rather short single parts were referred to, based on the principle of synecdoche, as 'oratorios'. And also here the entries in the account books remain consistent with the results of the lyrics analysis - a term 'Compositori musices pro 5 oratoriis' begins to surface from 1755. Moreover, the information about ' 5 oratorios' can be found only in the section regarding the novena in honor of St. Francis Xavier. The description above, emerging from the surviving documents, is clearly consistent with the structure of Ivanschiz's Oratorios, which - as mentioned above - are comprised of an instrumental introduction, recitative, aria da capo and a final chorus.

Almost none of the manuscripts from Graz cathedral has been preserved, even though they were still known at the beginning of the $20^{\text {th }}$ century. Thanks to Anton Seydler, and his article entitled Geschichte des Domchores in Graz ${ }^{15}$ we know that the majority of the currently lost Oratorios by other composers were identical in form with Ivanschiz's works. As Catalogus musicalium from 1773 indicates, compositions of this genre constituted an important part of the repertoire - the list includes 160 arias, 105 symphonies, 61 masses, 44 litanies, 32 oratorios, 22 Salve Regina, 17 Alma redemptoris, 15 vespers, 13 Advent songs, 12 Requiem, 10 Regina coeli and 8 Veni Sancte Spiritus. ${ }^{16}$ Unfortunately, we do not know the authors of these works. In the account books - beside Ivanschiz - such names as Johann Georg Zechner, Ägydius Schenk, Georg Christoph Wagenseil or Joseph Paul Ziegler are mentioned.

Quite evidently Oratorios in this form were related to the nature of musical life and liturgical tradition of the Jesuit College in Graz. ${ }^{17}$ Among the musicalia

13 The term 'part' would denote here 'larger units', where each included a few movements (arias, choruses etc.). For instance, a one-part composition Geistlicher Streit... dated 1715, was comprised of eight recitatives and arias, and a final chorus.

See: FLOTZINGER, op. cit., p. 24 et seq.

15 SEYDLER, Anton. Geschichte des Domchores in Graz von den Zeiten Erzherzogs Karl II. bis auf unsere Tage. Kirchenmusikalisches Jahrbuch. 1900, vol. 15, p. 33. As per KOHLBACH, Rochus. Der Dom zu Graz. Die fünf Rechnungsgebühren der Jesuiten. Graz, 1948, p. 178.

17 It is very likely that also in other Jesuit colleges of the Austrian Province novenas to St. Francis Xavier were accompanied by similar compositions, as is testified by the manuscript of Oratorio per la novenna di Santo Xaverio ascribed to G. Ch. Wagenseil, from Bratislavan Jesuits collection. The Oratorio comprises four parts marked 'Giorno I, II, III and IV', with the form identical with Ivanschiz's Oratorios. The terms used in the sources are similar, too 
kept in Pannonhalma, which used to belong to Jesuits from Györ, there remains 17 compositions called as such ${ }^{18}$ that most likely originate from the capital of Styria. Apart from six items bearing Ivanschiz's name, we also find there seven pieces by Wilhelm Wirth (c. 1743-1778, a composer, who in his youth, was connected with the Jesuit College in Graz), one by Joseph Holzinger and four anonymous manuscripts, including one incomplete copy of Oratorium Xaverianum by Fr. Amandus.

As it follows from the account books (we shall mention here again that the annotations regarding the oratorios begin in the section Pro Sacello S. Xaverii), a small St. Francis Xavier Chapel, still in existence today, ornate with the paintings that depict scenes from the life of this Jesuit missionary, made a natural scenery for the performance of these compositions. It was erected on the northern wall of St. Ägidius Church in 1659. ${ }^{19}$

The key conclusions regarding the works by Ivanschiz could be summarized as follows:

1. Oratorios marked with numbers $1-5$ do not constitute a set of completely separate works, but de facto a one, five-part cyclic composition (this is also indirectly confirmed by a symmetrical tonal structure: $\mathrm{C}-\mathrm{D}-\mathrm{C}-\mathrm{D}-\mathrm{C})$; musically complete parts of which were performed separately in consecutive odd days of novena.

2. All Latin Oratorios are contrafacta; originally they were most likely composed to German lyrics, dedicated to St. Francis Xavier. It is hard to say whether the Latin texts were written in Györ, or in Graz. Even though the second option seems less likely, it should still be considered possible - many facts indicate that, sporadically, also in this center, instead of commissioning new works, different words were added to older compositions. It can be proved by the following notes in the account books: 'Compilatori musicae', 'Regenti chori pro musica coordinata et eius descriptio curato', ${ }^{20}$ and most of all: 'Nova musica non est composita, sed tantum textus accomodatus'. ${ }^{21}$

3. Most probably the two surviving German Oratorios originally belonged to an analogous five-part cycle, today incomplete. Their lyrics may be considered authentic, which can be also confirmed by the fact, that texts incipits of all

- in both cases the instrumental introductions are called 'Introduzzione'. It is not out of question that Wagenseil's work comes from Graz, since his name is found in the college's account books. This issue, however, calls for further research. I wish to thank Dr. Ladislav Kačic for bringing this composition to my attention.

18 In the inventory of music from Györ, compiled in 1773 there are 21 Oratorios; however, not all of them have survived till our times; see: KIM, Katalin and Katalin SZACSVAI. Dokumente über das Musikleben der Jesuiten. Instrumenten- und Musikalienverzeichnisse zur Zeit der Auflösungen. Studia Musicologica Academiae Scientiarum Hungaricae. 1998, vol. 39, no. 2/4, especially p. 348-359.

19 KOHLBACH, op. cit., p. 125 et seq.

20 A-Gd, call no. XX-C-11 (1743), see: FLOTZINGER, op. cit., p. 27.

21 A-Gd, call no. XX-C-11 (1741). 
movements of the Oratorium Xaverianum in the manuscripts from Seckau ${ }^{22}$ and Pannonhalma are identical.

Translated by Paweł Wróbel and Maciej Jochymczyk

Maciej Jochymczyk (maciek.jochymczyk@gmail.com), Jagiellonian University, Kraków.

\title{
ABSTRACT \\ ORATORIOS BY AMANDUS IVANSCHIZ IN THE CONTEXT OF MUSI- CAL SOURCES AND LITURGICAL PRACTICE
}

\begin{abstract}
Among the works by Amandus Ivanschiz OSPPE (1727-1758) there is a number of compositions entitled Oratorios that do not fit the accepted definitions of the genre. The pieces, as we know them today, are short religious cantatas with texts praising Jesuit saints. The purpose of this text is to give an overview of the critical analysis of the preserved musical sources and the assessment of their credibility, as well as putting Ivanschiz's Oratorios in the context of liturgical tradition of Jesuits from Graz, for whom the compositions were written. Such an approach enables us to clarify the adopted definition of the genre and the role the music initially played. As it follows from the preserved music sources and account books from the St. Ägidius Church in Graz, the five Latin Oratorios do not constitute a set of completely separate works, but de facto a one, five-part cyclic composition, musically complete parts of which were performed separately in consecutive odd days of novena. All mentioned works are contrafacta; originally they were composed to German lyrics, dedicated to St. Francis Xavier. Quite evidently Oratorios in this form were related to the nature of musical life and liturgical tradition of the Jesuit College in Graz.
\end{abstract}

\section{Key words}

Amandus Ivanschiz, Oratorium, Graz, Jesuits, contrafactum, St. Francis Xavier

\section{Bibliography}

FLOTZINGER, Rudolf. Die Anfänge des Oratoriums in Graz. Historisches Jahrbuch der Stadt Graz, 1986, no. 16/17.

JOCHYMCZYK, Maciej (ed.). Amandus Ivanschiz: Missa in C. Musica Claromontana vol. 10, Cracow, 2013.

JOCHYMCZYK, Maciej. Twórczość religijna o. Amanda Ivanschiza OSPPE [Religious music by Fr. Amandus Ivanschiz OSPPE]. Doctoral dissertation, Institute of Musicology, Jagiellonian University, Cracow, 2012.

22 Although the current location of the manuscript is unknown, the copies of incipits of all the movements of the composition have survived in the work by POKORN, Danilo. Amandus Ivančič in njegovo posvetno skladateljsko delo. Doctoral dissertation, University of Ljubljana, 1977, p. 117. 
KIM, Katalin and Katalin SZACSVAI. Dokumente über das Musikleben der Jesuiten. Instrumenten- und Musikalienverzeichnisse zur Zeit der Auflösungen. Studia Musicologica Academiae Scientiarum Hungaricae. 1998, vol. 39, no. 2/4.

KOHLBACH, Rochus. Der Dom zu Graz. Die fünf Rechnungsgebühren der Jesuiten. Graz, 1948.

POKORN, Danilo. Amandus Ivančič in njegovo posvetno skladateljsko delo. Doctoral dissertation, University of Ljubljana, 1977.

SEYDLER, Anton. Geschichte des Domchores in Graz von den Zeiten Erzherzogs Karl II. bis auf unsere Tage. Kirchenmusikalisches Jahrbuch. 1900, vol. 15.

SMITHER, Howard E. A History of the Oratorio. Vol. 2: The Oratorio in the Baroque Era: Protestant Germany and England. Chapel Hill, 1977.

SMITHER, Howard E. A History of the Oratorio. Vol. 3: The Oratorio in the Classical Era. Oxford, 1987.

SULZER, Johann Georg. Allgemeine Theorie der Schönen Künste. Vol. 1. Leipzig, 1771. 